\title{
Location of superoxide anion generation in human colonic mucosa obtained by biopsy
}

\author{
N Oshitani, A Kitano, H Okabe, S Nakamura, T Matsumoto, K Kobayashi
} Internal Medicine, Osaka City University Medical School, 1-5-7 Asahimachi, Abeno-ku, Osaka 545, Japan

N Oshitan

H Okabe

S Nakamura

T Matsumoto

K Kobayashi

Ashihara Hospital, Japan A Kitano

Dr N Oshitani.

Accepted for publication
Third Department of

Correspondence to:

10 November 1992

\begin{abstract}
To identify which cells generate superoxide, inflamed human mucosa was tested with nitroblue tetrazolium as a probe, because it is reduced by strong reducing agents to form insoluble blue formazan, which then precipitates in tissues. Biopsy specimens from control subjects and patients with ulcerative colitis were studied. The specimens were organ cultured with bubbling air or nitrogen, and inhibition of the reduction by catalase ( $a$ hydrogen peroxide scavenger), para-benzoquinone (a tissue permeable superoxide scavenger), or superoxide dismutase (a superoxide scavenger) was assayed. The dye was reduced by epithelial cells, vascular endothelium, and infiltrating mononuclear cells of the mucosa. Its reduction by vascular endothelium and infiltrating mononuclear cells was greater in inflamed mucosa. The reduction by vascular endothelium and infiltrating mononuclear cells was inhibited in cultures with nitrogen saturation or with $1 \mathrm{mM}$ para-benzoquinone. The vascular endothelium seems to produce superoxide in the inflamed mucosa, which would exacerbate tissue injury in ulcerative colitis.

(Gut 1993; 34: 936-938)
\end{abstract}

The aetiology of ulcerative colitis is unclear. The number of mononuclear phagocytes is high at the

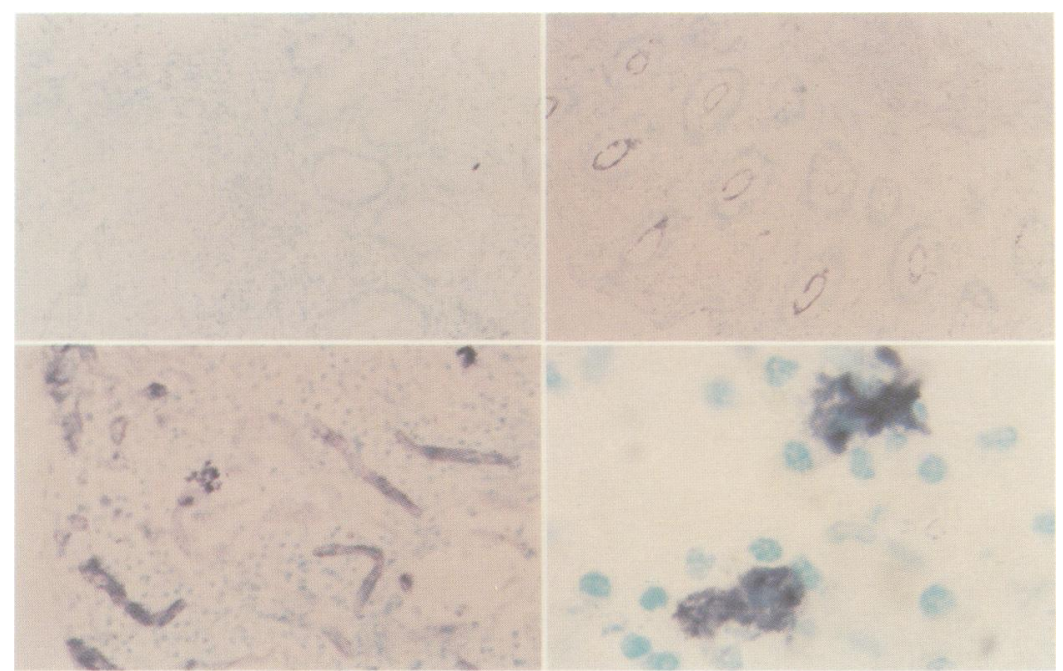

Top left: 38 year old woman with active ulcerative colitis. Reduction of nitroblue tetrazolium was strongly inhibited by the vascular endothelium and infiltrating mononuclear cells with the addition of $1 \mathrm{mM}$ para-benzoquinone (original magnification $\times 200$ ).

Top right: 76 year old man with no evidence of colonic disease. Formazan is seen at the brush border of the epithelial cells (original magnification $\times 200$ ).

Bottom left: Same patient as in top left. Formazan has been deposited at the brush border of the epithelial cells and in the vascular endothelium and infiltrating mononuclear cells (original magnification $\times 400$ ).

Bottom right: 37 year old woman with active ulcerative colitis. Mononuclear cells have reduced nitroblue tetrazolium (original magnification $\times 1000$ ). site of inflammation, which suggests that these cells participate in the pathogenesis and resolution of the tissue damage by releasing enzymes or generating toxic oxygen metabolites. ${ }^{2}$ Reactive oxygen species have a role in ischaemiareperfusion injury of the intestine, ${ }^{34}$ and may also participate in the pathogenesis of several kinds of gastric lesions. ${ }^{56}$ The role of reactive oxygen species in ulcerative colitis has been studied by the use of circulating or isolated phagocytic cells of patients with this disease. ${ }^{7-9}$ It is not known, however, if the production of reactive oxygen species by neutrophils or mononuclear cells in colonic mucosa is higher than normal in ulcerative colitis.

We used the reduction of nitroblue tetrazolium to detect the generation of superoxide in inflamed colonic mucosa. The soluble yellow form of nitroblue tetrazolium is reduced by strong reducing agents such as superoxide to form blue formazan, which is insoluble, precipitating in tissues. ${ }^{10}$ Inhibition assays were undertaken in anaerobic cultures with nitrogen saturation and the addition of para-benzoquinone, a superoxide scavenger that can permeate tissues.

\section{Methods}

Specimens were taken from the sigmoid colon (about $20 \mathrm{~cm}$ from the anus) of 28 patients with ulcerative colitis (mean age, 35 years; range, 15-59 years; 10 men and 18 women) and 23 controls without ulcerative colitis (mean age, 52 years; range, 20-73 years) who had sigmoidoscopy because of suspected non-inflammatory bowel disease. Specimens were washed with physiological saline containing $100 \mathrm{U} / \mathrm{ml}$ penicillin $\mathrm{G}$ and $100 \mu \mathrm{g} / \mathrm{ml}$ streptomycin. For aerobic and anaerobic culture, each specimen was placed in a screw capped culture bottle and $4 \mathrm{ml}$ of Eagle's minimum essential medium (MEM) were added. The specimens were organ cultured for one hour at room temperature with bubbling air or nitrogen. The medium was then replaced with $4 \mathrm{ml}$ of MEM containing $0.1 \mathrm{mg}$ / $\mathrm{ml}$ nitroblue tetrazolium, and the specimen was cultured for one hour more with air or nitrogen saturation, without switching.

A further assay of nitroblue tetrazolium reduction was undertaken with catalase, parabenzoquinone, or superoxide dismutase. Specimens were placed in a tissue culture plate (Falcon 3847 multiwell plate, Becton Dickinson and Cox) and cultured with $0.4 \mathrm{ml}$ of MEM alone or with catalase, para-benzoquinone, or superoxide dismutase added. The medium was then changed to $0.4 \mathrm{ml}$ of MEM containing $0.1 \mathrm{mg} / \mathrm{ml}$ nitroblue tetrazolium, with or without an addition. 
Tissue specimens were then fixed with periodate-lysine-2\% paraformaldehyde for six hours at $4^{\circ} \mathrm{C}$ and washed three times with increasing concentrations of sucrose $(10,15$, and $20 \%$ ). The fixed specimens were embedded in Tissue Tek OCT compound (Miles Pharmaceutical, Naperville, IL) and frozen in ethanol cooled with dry ice. Cryostat sections about $5 \mu \mathrm{m}$ thick were prepared and stained with methyl green for examination under a light microscope.

Deposits of formazan were graded as follows. For epithelial cells, 0 was negative, 1 was weakly positive, 2 was strongly positive, and 3 was very strongly positive. For the vascular endothelium, 0 was negative, 1 was weakly positive in places, 2 was diffuse and weakly positive, and 3 was diffuse and strongly positive. Mononulcear cells stained for formazan were found in various locations at various densities, but they aggregated to form clusters in some specimens, so the presence or absence of these clusters (at least three mononuclear cells grouped together) was recorded.

All sections were coded and then analysed for the relationship between nitroblue tetrazolium deposits and the degree of inflammation. Inflammation was graded according to Matt's criteria" by one of the authors, who was given no clinical information. Data were analysed by the $\chi^{2}$ test.

\section{Results}

Deposits of formazan were found in the colonic epithelium, vascular endothelium, and infiltrating mononuclear cells. Nitroblue tetrazolium reduction by the vascular endothelium and infiltrating mononuclear cells was strongly inhibited in the cultures with nitrogen saturation or those to which $1 \mathrm{mM}$ para-benzoquinone had been added, and reduction by the epithelial cells was partly inhibited in these circumstances (Fig (top left)). Catalase and superoxide dismutase, which were tested at concentrations of up to $3000 \mathrm{U} / \mathrm{ml}$, did not inhibit nitroblue tetrazolium reduction.

Nitroblue tetrazolium was reduced at the brush border of the colonic epithelium in the control tissue (Fig (top right)) and in specimens from ulcerative colitis patients (Fig (bottom left)). There was no difference between the degree of nitroblue tetrazolium deposit and the degree of tissue inflammation in the colonic epithelium (Table I). In specimens of inflamed mucosa, vascular endothelium strongly reduced nitroblue tetrazolium (Fig (bottom left)), but in the control mucosa, reduction was weak or absent (Fig (top right)). The reduction of nitroblue tetrazolium by the vascular endothelium increased with the degree of inflammation (Table II, $\mathrm{p}<0.05)$. Mononuclear cells that infiltrated the inflamed mucosa reduced nitroblue tetrazolium (Fig (bottom right)) and sometimes formed clusters, especially in active ulcerative colitis. Mononuclear cell clusters stained with formazan were found in inflamed mucosa only (Table III, $\mathrm{p}<0.01$ ).

\section{Discussion}

Phagocytic cells are found in the intestinal
TABLE I Reduction of nitroblue tetrazolium (NBT) by colonic epithelium in patients with ulcerative colitis (UC) and in control subjects

\begin{tabular}{lclll}
\hline & & \multicolumn{2}{l}{$\begin{array}{l}\text { Number of UC patients with } \\
\text { degree of inflammation by Matts } \\
\text { criteria }\end{array}$} \\
\cline { 3 - 5 } $\begin{array}{l}\text { Degree } \\
\text { of NBT } \\
\text { reduction }\end{array}$ & $\begin{array}{l}\text { No of } \\
\text { controls }\end{array}$ & 1 & $2-3$ & $4-5$ \\
\hline 0 & 0 & 1 & 0 & 1 \\
1 & 12 & 3 & 9 & 6 \\
2 & 9 & 0 & 2 & 3 \\
3 & 2 & 0 & 3 & 0 \\
\hline
\end{tabular}

TABLE II Reduction of nitroblue tetrazolium (NBT) by vascular endothelium in patients with ulcerative colitis (UC) and in control subjects

\begin{tabular}{|c|c|c|c|c|}
\hline \multirow{2}{*}{$\begin{array}{l}\text { Degree } \\
\text { of NBT } \\
\text { reduction }\end{array}$} & \multirow{2}{*}{$\begin{array}{l}\text { No of } \\
\text { controls }\end{array}$} & \multicolumn{3}{|c|}{$\begin{array}{l}\text { Number of UC patients with } \\
\text { degree of inflammation by Matts' } \\
\text { criteria }\end{array}$} \\
\hline & & 1 & $2-3$ & $4-5$ \\
\hline $\begin{array}{l}0 \\
1 \\
2 \\
3\end{array}$ & $\begin{array}{r}4 \\
14 \\
5 \\
0\end{array}$ & $\begin{array}{l}2 \\
2 \\
0 \\
0\end{array}$ & $\begin{array}{l}0 \\
6 \\
6 \\
2\end{array}$ & $\begin{array}{l}0 \\
2 \\
6 \\
2\end{array}$ \\
\hline
\end{tabular}

$\chi^{2}, 20 \cdot 479 ; \mathrm{p}<0 \cdot 05(\mathrm{df}=9)$.

TABLE III Patients with ulcerative colitis (UC) and control subjects with or without clusters of mononuclear cells stained with formazan

\begin{tabular}{lllll}
\hline & & \multicolumn{2}{l}{$\begin{array}{l}\text { Number of UC patients with } \\
\text { degree of inflammation by Matts' } \\
\text { criteria }\end{array}$} \\
\cline { 3 - 5 } Clusters & $\begin{array}{l}\text { No of } \\
\text { controls }\end{array}$ & 1 & $2-3$ & $4-5$ \\
\hline Not found & 23 & 4 & 8 & 6 \\
Found & 0 & 0 & 6 & 4 \\
\hline
\end{tabular}

$\chi^{2}, 14 \cdot 024 ; \mathrm{p}<0.01(\mathrm{df}=3)$.

mucosa; they are heterogeneous immunohistochemically in both normal and inflamed mucosa. ${ }^{13}$ The number of activated macrophages is probably increased in inflamed ulcerative colitis mucosa, and these macrophages generate superoxide by membrane associated NADPH oxidase, which mediates antimicrobial and cytotoxic effects. ${ }^{2}$ Many of the circulating monocytes in patients with inflammatory bowe disease are activated. ${ }^{78}$ In a study of isolated macrophages, a greater proportion than normal of macrophages from the mucosa of ulcerative colitis patients underwent a respiratory burst to generate superoxide. ${ }^{9}$ These findings suggested that superoxide is involved in the pathogenesis of inflammatory bowel disease. Oxyradical dependent photoemission of granulocytes stimulated by platelet activating factor has been detected in vivo in rat mesenteric microvascular beds, ${ }^{14}$ but it is not known if these reactive oxygen species are generated in vivo in the colonic mucosa because phagocytes may be activated during isolation procedures used in in vitro studies.

The fact that nitroblue tetrazolium reduction was not inhibited by catalase or superoxide dismutase may be the result of a lack of tissue permeability of these enzymes. On the other hand, inhibited reduction of nitroblue tetrazolium by colonic vascular endothelium and mononuclear cells under anaerobic conditions or with the addition of $1 \mathrm{mM}$ para-benzoquinone may reflect the participation of reactive oxygen species in the reduction. Hydrogen peroxide and 
its metabolites do not reduce nitroblue tetrazolium, ${ }^{10}$ so superoxide may cause the reduction. The vascular endothelium may be essential for the occurrence of inflammatory or immunological phenomena. ${ }^{15}$ Xanthine oxidase has been found in the endothelium of capillaries by immunohistochemistry, ${ }^{16}$ and superoxide is generated in endothelial cell cultures. ${ }^{17}{ }^{18}$ Superoxide seems to be generated by the endothelium in inflamed colonic mucosa.

The activation of the endothelium may be the result of microbial attack, contact activation by activated neutrophils, or some other external stimulus, including inflammatory mediators. The superoxide generated may have a direct cytotoxic effect or it may interact with inflammatory mediators to modify the inflammatory process.

This work is supported by grant from the Ministry of Education, Japan.

1 Ganguly NK, Kingham JGC, Lloyd B, Lloyd RS, Price CP, Triger DR, et al. Acid hydrolases in monocytes from patients with inflammatory bowel disease, chronic liver disease, and rheumatoid arthritis. Lancet 1978; i: 1073-5.

2 Weiss SJ, LoBuglio AF. Phagocyte-generated oxygen metabolites and cellular injury. Lab Invest 1982; 47:5-18

3 Parks DA, Bulkley GB, Granger DN. Role of oxygen-derived free radicals in digestive tract diseases. Surgery 1983; 94: 415-22.

4 Granger DN, Rutili G, McCord JM. Superoxide radicals in feline intestinal ischemia. Gastroenterology 1981; 81: 22-9.

5 Perry MA, Wadhwa S, Parks DA, Pickard W, Granger DN Role of oxygen radicals in ischemia-induced lesions in the cat stomach. Gastroenterology 1986; 90: 362-7.

6 Yoshikawa T, Yoshida N, Miyagawa H, Takemura T,
Tanigawa T, Sugino S, et al. Role of lipid peroxidation in gastric mucosal lesions induced by burn shock in rats. $\mathcal{F}$ Clin Biochem Nutr 1987; 2: 163-70.

7 Williams JG, Hughes LE, Hallett MB. Toxic oxygen metabolite production by circulating phagocytic cells in inflammatory bowel disease. Gut 1990; 31: 187-93

8 Suematsu M, Suzuki M, Kitahora T, Miura S, Suzuki K, Hibi $T$, et al. Increased respiratory burst of leukocytes in inflammatory bowel diseases: the analysis of free radical generation by using chemiluminescence probe. F Clin Lab Immunol 1987; 24: 125-8.

9 Mahida YR, Wu KC, Jewell DP. Respiratory burst activity of intestinal macrophages in normal and inflammatory bowel intestinal macrophages in norm
disease. Gut 1989; 30: 1362-70.

10 DiGregorio KA, Cilento EV, Lantz RC. Measurement of superoxide release from single pulmonary alveolar macrophages. Am F Physiol 1987; 252: C677-83.

11 Matts SGF. The value of rectal biopsy in the diagnosis of ulcerative colitis. Qf Med 1961; 30: 393-407.

12 Selby WS, Poulter LW, Hobbs S, Jewell DP, Janossy G. Heterogeneity of HLA-DR-positive histiocytes in human intestinal lamina propria: a combined histochemical and immunohistological analysis. $\mathcal{f}$ Clin Pathol 1983; 36: 379 84.

13 Mahida YR, Patel S, Gionchetti P, Vaux D, Jewell DP. Macrophage subpopulations in lamina propria of normal and Macrophage subpopulations in lamina propria of normal and

14 Suematsu M, Kurose I, Asako H, Miura S, Tsuchiya M. In vivo visualization of oxyradical-dependent photoemission during endothelium-granulocyte interaction in microvascular beds treated with platelet-activating factor. f Biochem 1989; 106: 355-60.

15 Matsumoto T, Kitano A, Nakamura S, Oshitani N, Obata A, Hiki M, et al. Possible role of vascular endothelial cells in immune responses in colonic mucosa examined immunocytochemically in subjects with and without ulcerative colitis. Clin Exp Immunol 1989; 78: 424-30.

16 Jarasch E-D, Bruder G, Heid HW. Significance of xanthine oxidase in capillary endothelial cells. Acta Physiol Scand 1986; 548 suppl: $39-46$.

17 Ratych RE, Chuknyiska RS, Bulkley GB. The primary localization of free radical generation after anoxia reoxygenation in isolated endothelial cells. Surgery 1987; 102: 122-31.

18 Phan SH, Gannon DE, Varani J, Ryan US, Ward PA. Xanthine oxidase activity in rat pulmonary artery endothelial cells and its alteration by activated neutrophils. $A m \mathcal{F}$ 